\title{
Population growth and cyst production of the rotifer Brachionus plicatilis (Monogonta: Brachionidae) fed with three different diets
}

\author{
A. A. Ortega-Salas, C. I. Reyes and H. Reyes-Bustamante \\ Unidad Académica Mazatlán, Instituto de Ciencias del Mar y Limnología, Universidad Nacional Autónoma de México, Calzada Joel Montes \\ Camarena s/n Mazatlán, 82040, Sinaloa, México; ortsal@ola.icmyl.unam.mx
}

Received 12-II-2013 Corrected 29-IV-2013 Accepted 6-VII-2013

\begin{abstract}
This study compares the effect of different diets on population growth, fecundity rate, production, and cyst hatching efficiency of the rotifer Brachionus plicatilis. Microalgae were cultured using filtered and sterilized seawater at 25 and $26^{\circ} \mathrm{C}$. The volume of the containers for algae, bread yeast, and rotifer was duplicated daily from $31 \mathrm{~mL}$ to $16 \mathrm{~L}$ in nine days. Rotifers were cultured at $25^{\circ} \mathrm{C}$ and $35 \%$ salinity. The mean values of daily population growth rate for the rotifers fed on C. muelleri, I. galbana and bread yeast were $0,91,0,89$ and 0,87 daily counts, respectively. After 10 cultured days, fecundity was $72 \%, 63 \%$ and $36 \%$ using C. muelleri, I. galbana and bread yeast, respectively. The highest mean value for cysts production was 4064000 cysts found from 63243 (1,55\%) rotifers fed on C. muelleri. Hatching efficiency after 36 hours of cysts from rotifers fed C. muelleri was 51500 (94,3\%) new borns, followed by 45000 (93,3\%) with I. galbana, and 31000 (92,6\%) with bread yeast. C. muelleri is a good food source for B. plicatilis.
\end{abstract}

KEY WORDS

Fecundity, feeding, hatching, salinity, temperature

\begin{abstract}
RESUMEN
Este estudio compara el efecto de la dieta alimenticia en el crecimiento poblacional, la tasa de fecundidad, producción y eficiencia de desove de quistes en el rotífero Brachionus plicatilis. Para la producción de microalgas, el agua marina se filtró sucesivamente y se mantuvo entre $25^{\circ} \mathrm{y}$ $26^{\circ} \mathrm{C}$. El volumen de los contenedores para algas, levadura y rotíferos se duplicó diariamente de $31 \mathrm{~mL}$ a $16 \mathrm{~L}$ en nueve días. Los rotíferos se mantuvieron a temperaturas de $25^{\circ} \mathrm{C}$ y salinidad de $35 \%$. La tasa de crecimiento de los rotíferos por día fue de 0,91 alimentados con C. muelleri, 0,89 con I. galbana y de 0,87 con levadura. La fecundidad de los rotíferos 10 días fue de 0,72 cuando fueron alimentados con C. muelleri, 0,63 con I. galbana y 0,36 con levadura. La producción más alta de quistes fue de $63243(1,55 \%)$ a partir de 4064000 rotíferos cuando se alimentan con C. muelleri. La eficiencia de desove de quistes de rotíferos alimentados con C. muelleri fue de 51500 (94,6\%) de neonatos después de 36 horas, 45 000 (93,3\%) con la dieta de I. galbana y de 31000 (92,6\%) con levadura. C. muelleri mostró ser una buena fuente de alimentación.
\end{abstract}

\section{PALABRAS CLAVE}

Alimentación, desove, fecundidad, temperatura, salinidad
In order to expand the practice of marine finfish larvae rearing, it is necessary to increase and stabilize the production of live feed. The technology is based on the use of highly concentrated algal biomass as food for the rotifers. Villegas, Millamena and Escritor (2008) studied the effects of three selected algal species, Tetraselmis tetrahele, Isochrysis galbana, and marine Chlorella sp., on the population growth of Brachionus plicatilis after three, five and seven days of culture. The rotifers fed on T. tetrahele showed growth with a mean peak density of 92,5 individuals per $\mathrm{mL}$. This result was superior to those fed on $I$. galbana (48,2 individuals per $\mathrm{mL})$ and Chlorella sp. $(47,2$ individuals per $\mathrm{mL}$ ) in five days. Rotifers are mass-cultured at 10 000-30 000 individuals $\mathrm{mL}-1$ by feeding them exclusively on condensed freshwater Chlorella. The cultures are generally supplied with $\mathrm{O}_{2}$ at a constant rate; and the $\mathrm{pH}$ is adjusted to 7 by addition of $\mathrm{HCl}$ to avoid an increase of free ammonia in the culture system, substituted rotifers for Artemia in larval fish culture. He is using a new, continuous culture system that appears to be reliable and stable. It is still in the development phase, but he is averaging about $8 \mathrm{Kg}$ of wet weight rotifers per day. Rotifer production has very significant economies of scale. Labor cost is almost independent of production levels. He is 
using yeast and other nutrients in a continuous production system with L-type rotifers. Apparently large rotifer production systems will solve the cost of producing live Artemia nauplii; hence, it is important to know the biology of rotifers and their nutritional requirements to optimize their culture. Since the supply of rotifers does not always meet the demand, it is necessary to apply techniques to produce high quality cysts that can be used to initiate rotifer culture systems on a large scale.

The aim of this study was to compare the population growth rate of $B$. plicatilis, production of cysts, fecundity rate (Release eggs/Eggs in each female in the sample), and efficiency of hatching when the rotifers where fed on the microalgae Chaetoceros muelleri Lemmermann, or Isochrysis galbana Bruce, Knight and Parke, or baker's yeast Saccharomyses cerevisiae strain Lalvin EC1118 (Prise de mousse) as food.

\section{MATERIAL AND METHODS}

This study was performed at the Aquaculture Laboratory, Facultad de Ciencias del Mar, Universidad Autónoma de Sinaloa, using two rooms: one, to culture microalgae, which was provided with 13 white-light lamps from 40 to $75 \mathrm{~W}$, and the other, for the culture of rotifers. Each room has a water aeration system for culturing C. muelleri (CHGRA) (Lora-Vilchis, Cordero \& Voltolina, 2004), I. galbana microalgae and rotifers.

There are two main sizes for B. plicatilis, small (S) and large (L); they differ in the lorica length, which is 100$210 \mu \mathrm{m}$ (mean 160 $\mu \mathrm{m}$ ) for S type B. rotundiformis (Gómez, 2005) and $130-340 \mu m$ (mean $239 \mu \mathrm{m}$ ) for $L$ type. In this study the $L$ type was used. The rotifer strains were isolated from an oasis in San Pedro, Baja California (Ramírez-Sevilla, Rueda Jasso, Ortiz-Galindo \& González-Acosta, 1991). Their cysts are yellow-brown, rounded, and wrinkled on the surface, with diameters of $10 \mu \mathrm{m}(25 \%), 11 \mu \mathrm{m}(60 \%)$ and $12 \mu \mathrm{m}(15 \%)$.

The seawater for culturing microalgae was filtered successively through filters of 5,0, 1,0, and $0,45 \mu \mathrm{m}$ (Reyes, 2003), ultraviolet radiation was used to sterilize the water; controlled temperature between $25^{\circ}$ and $26^{\circ} \mathrm{C}$ was maintained to permit the rotifer population grow adequately. The rotifers were initially maintained in $500 \mathrm{~mL}$ flasks at a temperature of $25^{\circ} \mathrm{C}$ and salinity of $35 \%$ and fed on microalgae or bread yeast. C. muelleri measures between 4 and $7 \mu \mathrm{m}$ in diameter by 6 to $8 \mu \mathrm{m}$ in length, whereas I. galbana measures $8 \mu \mathrm{m}$ in diameter by 11 to $13 \mu \mathrm{m}$ in length (Ortega, 1984; Trujillo \& Voltolina 1994). The production of microalgae according to Matthiessen and Toner (1966) method, doubling the volume of the containers daily from $31 \mathrm{~mL}$ to $16 \mathrm{~L}$ in nine days.

The rotifer culture started 10 to 20 organisms $/ \mathrm{mL}$. The growth of the rotifer population was assessed by daily counts according to Yúfera and Pascual (1980) with the formula $\mathrm{Ke}=(\ln \mathrm{Nt}-\ln \mathrm{NO}) / \mathrm{T}$, where $\mathrm{NO}$ is the number of organisms at the start of a period of T days, and Nt the number after $\mathrm{T}$ days. The population growth was assessed in triplicate each sampling. The rotifers were fed each one of the two selected microalgae at a density of $1 \times 10^{6} \mathrm{cells} /$ $\mathrm{mL}$, and bread yeast dissolving $1 \mathrm{~g}$ in $20 \mathrm{~L}$ seawater each day. The volume of the rotifers culture was doubled daily from $31 \mathrm{~mL}$ tubes to $16 \mathrm{~L}$ containers in nine days. Each day the rotifers were concentrated in a sieve and transfer to the next volume containing the algae's and the bread yeast.

The fecundity rate $A_{f}=H / n$ was estimated from the number of eggs released per eggs in each female, where $\mathrm{H}$ is the total number of eggs released and $\mathrm{n}$ is the number of females which have eggs in the sample (Table 1).

Production of cysts from three essays: rotifers were filtered into $18 \mathrm{~L}$ flask $2 \times 10^{6} \mathrm{cels} / \mathrm{ml}$ density of the designed microalgae for rotifers to feed, daily, also rotifers were filtered in $1 \mathrm{~g}$ of bread yeast in $18 \mathrm{~L}$ flask, until density reached more than $100 \mathrm{rot} / \mathrm{mL}$, then feeding stopped; sexual reproduction started (mictic), 5 days later rotifers were filtered using a $60 \mu \mathrm{m}$ mesh, one $20^{\text {th }}$ part of the volume was evaporated by light sun rays then cysts were cleaning using brine water and mixed with the

TABLE 1

Final concentration of B. plicatilis with different foods*

\begin{tabular}{ccccc}
\hline & $\begin{array}{c}\text { E. in } \\
\text { Female/mL }\end{array}$ & L. Eggs/mL & Rotif+Eggs & Fecundity \\
\hline \multicolumn{5}{c}{ C. muelleri } \\
\hline Mean & 79,6 & 30,7 & 108 & 0,34 \\
SD & 44,5 & 23,8 & 65,8 & 0,15 \\
\hline \multicolumn{5}{c}{ I. galbana } \\
\hline Mean & 70,2 & 24 & 94,2 & 0,29 \\
SD & 32,4 & 26,7 & 56 & 0,2 \\
\hline \multirow{5}{5}{ Bread } \\
& yeast & \\
\hline Mean & 58,7 & 18,1 & 76,8 & 0,32 \\
SD & 27,5 & 8,7 & 35,7 & 0,08
\end{tabular}

${ }^{*}$ Considering increase of volume, eggs in female, number of release eggs, rotifers plus the eggs and fecundity rate in an increasing volume in 10 days 
substratum, then stir up for one minute, the cyst floated and were counted.

To evaluate the percentage of hatching, groups of 100 well preserved cysts were settled in a Petri dish with sterilized water, a $60 \mathrm{~W}$ lamp was placed at $60 \mathrm{~cm}$ for $24 \mathrm{~h}$, and the neonates were counted and separated until no more were born. The cysts were also decapsulated to obtain more neonates; they were settled with a mixture of $12 \mathrm{~mL}$ of sodium hypochlorite with $0,6 \mathrm{~mL}$ of sodium hydroxide at $40 \%$ for $15 \mathrm{~min}$, then watered, and $3 \mathrm{~mL}$ of sodium thiosulfite was added to neutralize them, and then they were watered again (US Patent 7258890 - Process for decapsulating crustacean or rotifer eggs) (Table 2 ).

Efficiency and rate of hatching: $0,1 \mathrm{~g}$ of cysts was settled in a $1 \mathrm{~L}$ flask with light and aeration for $24 \mathrm{~h}$ at $25^{\circ} \mathrm{C}$; using a $1 \mathrm{~mL}$ micropipette, neonates were count and extrapolate to $1 \mathrm{~g}$ cysts. The rate of hatching after $12 \mathrm{~h}$, the first count was made each hour in three samples until $90 \%$ of cyst hatched. T0 $(10 \%)=$ time when the first neonate hatched, until $T_{90}(90 \%) T_{s}=T_{90}-T_{0}$ (Table 2) where $T s$ is the synchronized time (Table 2).

The ANOVA and Kruskal Wallis statistical methods were used.

\section{RESULTS}

Mean daily population growth rate ke for rotifers was 0,91 ( $\pm 0,09 S D$ ) fed on C. muelleri, 0,89 ( $\pm 0.05 S D$ ) on I. galba$n a$ and $0,87( \pm 0,09 S D)$ on bread yeast; these rates showed no significant differences between $C$. muelleri and bread yeast, or between C. muelleri and I. galbana $(\mathrm{P}=2,77)$ under a crescent culture (Fig. 1 and 2). The average fecundity rate was relatively higher with $C$. muelleri $0,35( \pm 0,15 \mathrm{SD})$ as compared to bread yeast $0,29( \pm 0.2 \mathrm{SD})$ and I. galbana $0,33( \pm 0,08 \mathrm{SD})$, but no significant differences were fed among diets (Table 1).

Table 2 shows the mean number of rotifers plus eggs in the 16 containers on day ten was $4064000 \pm 741717$ fed with C muelleri, $3221333 \pm 720059$ with I. galbana 2762 $667 \pm 345516$ and with bread yeast (Fig. 1 and 2).

The highest mean production of cysts was 63 243(1,55\%); C. muelleri was used as food. The percentage of hatching was higher at $24 \mathrm{~h}$ time intervals. Efficiency of hatch extrapolate to $1 \mathrm{~g}$ of cysts from rotifers fed with C. muelleri was 51 500(94,3\%) neonates at 36h (Table 2). ANOVA showed no significant differences between $C$. muelleri and bread yeast, or between C. muelleri and I. galbana $(F 2,27, P<0,05)$. The percentage of hatching varied

TABLE 2

Production of cysts, interval of hatching, hatching efficiency, and percentage of hatching from cysts after C. muelleri, I. galbana, or bread yeast had been fed to rotifers.

\begin{tabular}{|c|c|c|c|c|c|c|c|c|}
\hline & \multirow{2}{*}{$\begin{array}{c}\text { Number of } \\
\text { rotifers }\end{array}$} & \multirow{2}{*}{$\begin{array}{c}\text { Cysts } \\
\text { produced }\end{array}$} & \multirow[t]{2}{*}{$\%$ cysts } & \multicolumn{3}{|c|}{$\%$ hatched after time intervals } & \multirow{2}{*}{$\begin{array}{l}\text { Hatching } \\
\text { efficiency/g }\end{array}$} & \multirow{2}{*}{$\begin{array}{c}\% \text { of } \\
\text { hatching }\end{array}$} \\
\hline & & & & $12 \mathrm{~h}$ & $24 h$ & $36 \mathrm{~h}$ & & \\
\hline & & \multicolumn{7}{|c|}{ C. muelleri } \\
\hline Mean & 4064000 & 63243 & 1,55 & 17,3 & 75 & 7,6 & 51500 & 94,3 \\
\hline \multirow[t]{2}{*}{ SD } & 741717 & 3568 & 0,35 & 3,51 & 5,2 & 2,5 & 2500 & 2,52 \\
\hline & & \multicolumn{7}{|c|}{ I. galbana } \\
\hline Mean & 3221333 & 15402 & 0,47 & 18 & 75 & 7 & 45000 & 93,3 \\
\hline \multirow[t]{2}{*}{ SD } & 720059 & 2329 & 0,21 & 2,65 & 2 & 1 & 2000 & 3 \\
\hline & & \multicolumn{7}{|c|}{ Bread yeast } \\
\hline Mean & 2762667 & 33383 & 1,21 & 16 & 73 & 10,6 & 31000 & 92,6 \\
\hline SD & 345516 & 2770 & 0,12 & 3 & 4,04 & 3,21 & 6557 & 2,52 \\
\hline
\end{tabular}




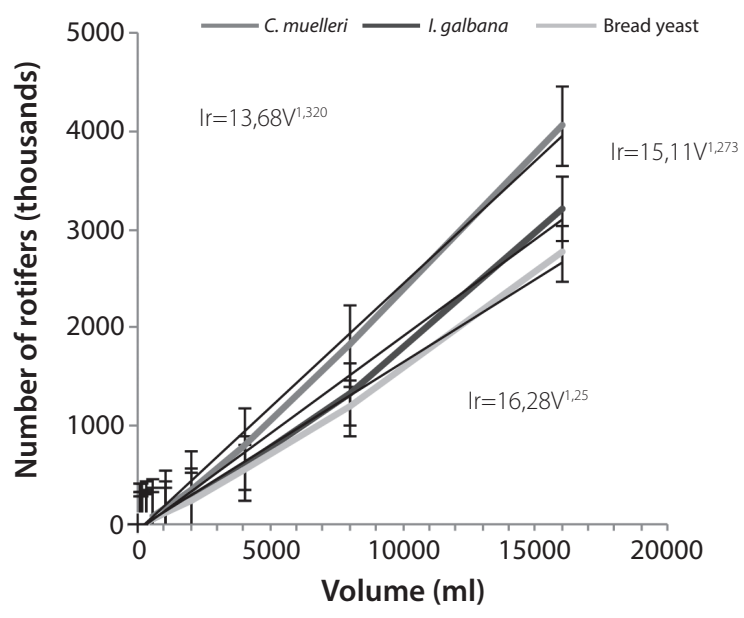

FIG. 1. Number of rotifers ( $\mathrm{Nr}$ ) as function of the increasing volume of the containers fed on microalgae and bread yeast. Regression lines and standard errors are shown.

from $92,6 \%$ fed rotifers bread yeast to $94,3 \%$ fed C. muelleri. This percentage decreases from about 90 in 15 days to less than 60 in 60 days.

Fecundity and cyst production showed that C. muelleri to be better food.

\section{DISCUSSION}

The size of the buccal cavity of a rotifer depends on the overall body size. The relationship between maximum size of the food ingested $(\mathrm{Tm})$ and lorica length $(\mathrm{L})$ is as follows: $\mathrm{Tm}=0,090 \mathrm{~L}-0,033$ (Hino \& Hirano, 1980). For rotifers between 250 and $300 \mu \mathrm{m}$, the maximum food ingested measured between 22 and $27 \mu \mathrm{m}$. In the present study, $B$. plicatilis had good results fed on C. muelleri, which in this case measured less than $10 \mu \mathrm{m}$ (Trujillo \& Voltolina, 1994).

The rate of ingestion increases with the concentration of the food up to a maximum level, then the ingestion rate remains constant (Hirata \& Mocawa, 1983). In the present study the hatching rate was $94,3 \%$ when food was C. muelleri.

Minkoff, Lubzens and Kahan (1983) mentioned that at 9\%o salinity, hatching of B. plicatilis was optimal (40-70\%) when the temperature was $10-30^{\circ} \mathrm{C}$ and decreased linearly with rise in incubation temperature. Light was obligatory for termination of dormancy. At $15^{\circ} \mathrm{C}$ resting eggs incubated over a salinity range of $9-40 \%$ s showed optimal

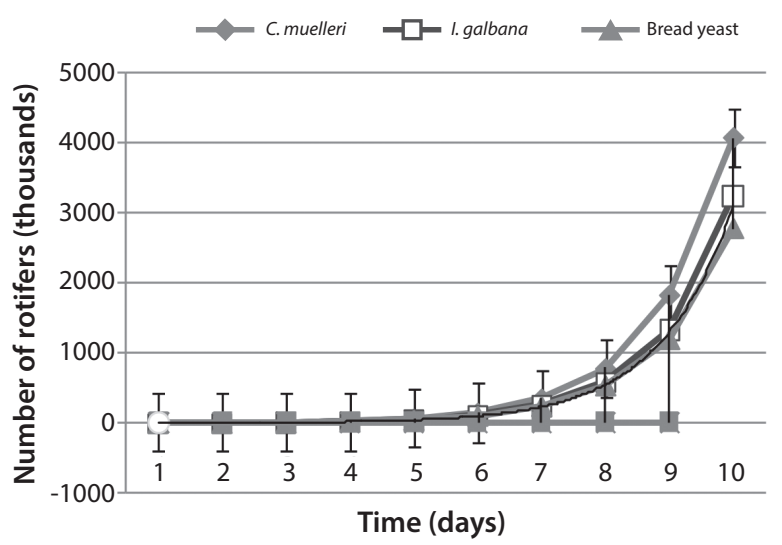

FIG. 2. Number of rotifers (Nr) as function of the increasing time fed on microalgae or bread yeast. Equations of the regression lines and standard error are shown.

hatching at $160 / 00$. In the present study at $25^{\circ} \mathrm{C}$ and salinity of $35 \%$ cysts were given light and aeration for $24 \mathrm{~h}$.

Frequent densities of rotifers in commercial cultures are 2500 rotifers $/ \mathrm{mL}$ in recirculation system (Suantika, Dhert \& Sorgeloos, 2003), although ultra densities of more than $1,6 \times 105 / \mathrm{mL}$ have been reported (Yoshimura, Tanaka \& Yoshimatsu, 2003). In the present study, the highest densities reached were of 254 rotifers+ eggs $/ \mathrm{mL}$ fed on C. muelleri, and the lowest was 172rotifers+eggs $/ \mathrm{mL}$ fed with bread yeast after 9 days of culture in $16 \mathrm{~L}$. C. muelleri showed to be better food.

\section{ACKNOWLEDGEMENTS}

We thank A. Nuñez P. and S. Rendón R. for technical support.

\section{REFERENCES}

Gómez, A. (2005). Molecular ecology of rotifers: from population differentiation to speciation. Hydrobiology, 546, 83-99. doi: 10.1007/s10750-005-4104-7

Hino, A., \& Hirano, V. (1980). Relationship between body size of the rotifer Brachionus plicatilis and the maximum size of particles ingested. Bulletin of the Japanese Society of Scientific Fisheries, 46(10), 1217-1222. 
Hirata, H. S., \& Mocawa, T. (1983). Continuous culture of the rotifer Brachionus plicatilis fed recycled algal diets. Hydrobiology, 104, 71-75.

Lora-Vilchis, M. C., Cordero, B. E., \& Voltolina, D. (2004). Growth of Artemia franciscana fed Isochrysis sp. and Chaetoceros muelleri during its early life stages. Aquaculture Research, 35, 1086-1091. doi: 10.1111/j.1365-2109.2004.01123.x

Matthiessen, C. G., \& Toner, R. G. (1966). Possible shellfish industry of Martha's Vineyard, Duke's County Massachussetts. Edgartown, Massachussets, USA: Marine Research Foundation.

Minkoff, G., Lubzens, E., \& Kahan, D. (1983). Environmental factors affecting hatching of rotifer (Brachionus plicatilis) resting eggs. Hydrobiology, 104(1), 61-69.

Ortega, M. M. (1984). Catálogo de algas continentales recientes de México UNAM. México: UNAM.

Ramírez-Sevilla, R., Rueda Jasso, R., Ortiz-Galindo, J. L., \& González-Acosta, B. (1991). Metodología para el cultivo del rotífero Brachionus plicatilis. Investigaciones Marinas CICIMAR, 6(2), 287-290.

Reyes C. (2003). Cultivo experimental del rotífero Brachionus plicatilis con tres diferentes dietas y el análisis de la calidad de los quistes. Tesis de licenciatura. Facultad Ciencias Marinas, Universidad Autónoma de Sinaloa, México.
Suantika, G., Dhert N. P., \& Sorgeloos, M. P. (2003). High-density production of the rotifer Brachionus plicatilis in a recirculation system: consideration of water quality, zootechnical and nutritional aspects. Aquaculture Engeniering, 21, 201-213. doi: 10.1016/S0144-8609(99)00031-X

Trujillo, M., \& Voltolina, D. (1994). Cultivos de microalgas para la acuicultura. Departamento de acuicultura. Centro de Investigación Científica y de Educación Superior de Ensenada, Baja California, México.

US Patent 7258890 - Process for decapsulating crustacean or rotifer eggs. US Patent Issued on August 21, (2007). Estimated Patent Expiration Date: May 13, 2023.USA.

Villegas C. T., Millamena, O., \& Escritor, F. (2008). Food value of Brachionus plicatilis fed three selected algal species as live food for milkfish, Chanos chanos Forsskal, fry production. Aquaculture Research, 21(2), 213 - 220.

Yoshimura, K., Tanaka, K., \& Yoshimatsu, T. (2003). Anovel culture system for the ultra-high-density production of the rotifer, Brachionus rotundiformis a preliminary report. Aquaculture, 227, 165-172.

Yúfera, M., \& Pascual, E. (1980). Estudio del rendimiento de cultivo del rotífero Brachionus plicatilis. Hydrobiology Society URRS, 44(2), 361-368. 
